\title{
Semantics and Psychanalysis of Criminal Investigation
}

\author{
Neculai Spirea Zamfirescu \\ Center for Applied Research, Romanian Society of Researchers in Judicial Strategies, Rm. Sarat, Romania
}

\author{
Email address: \\ info@psihocriminalistica.ro
}

\section{To cite this article:}

Neculai Spirea Zamfirescu. Semantics and Psychanalysis of Criminal Investigation. International Journal of Law and Society. Special Issue: Women and Digital Space: Knowledge, Expertise and Professional Empowerment. Vol. 3, No. 4, 2020, pp. 172-188.

doi: $10.11648 /$ j.ijls.20200304.14

Received: August 14, 2020; Accepted: September 18, 2020; Published: November 16, 2020

\begin{abstract}
This article brings before the interested parties several extracts from independent research reports made exclusively by the author of the article. The object of the research was to obtain favorable evidence through open applied research conducted through independent research, for and at the request of lawyers. In essence, research relies on knowing the state of mind from a semantic and psychoanalytic perspective, in order to identify: the false idea or conception, the act of intelligence that considers true what is false and vice versa; the mistake of breaking the rules of a demonstration; the mistake of interpreting or associating a person, a fact, a work, etc.; mistake in judgment or appreciation of things; suggestion; subjective or imperfect representation of reality due to the limits of knowledge; false representation of a situation which may serve as a cause for annulment of a decision or act; wrong establishment of facts that can lead to injustice. Thus: characterizing a recorded dialogue we inferred that it was preconstituted; in order to procure an information element we applied a computer program; by the method of equivalence of the terms we established the fact that the statement represents a report in which the witness reproduces aspects stored in the memory during the criminal investigation, not before; appealing to the theory of empathy, we established that the dialogues carried out are justified from the point of view of interprofessional reasons; based on the determination of the witness's personality, we inferred that he did not send any evidence that could affirm the incrimination; analyzing the testimony, I established that it cannot be stalked by falsity; the exploratory observations on the minutes of the resumption of the conversations established that the judge did not limit himself to the examination of a purely passive manner of the illicit activity, but exerted an influence likely to incite the commission of the crime that would not otherwise have been committed; analyzing a cryptographic text, we established that the synonymy of fears is excluded; Analyzing the text of a forged will, we established that although a will was served in favor of the legatee, it concerned only the fraction of movable property in the dwelling; the testimony of the witness was appreciated as faithfully reproducing the received event, presenting a high degree of certainty; by capitalizing on the free testimonial account, I established the individuality of the mode of operation, the biocriminalistic individuality and I drew up the tracking file of the unknown author; realizing the reconstruction of a crime scene, we established that the person who assumes the criminal action is not the perpetrator of the murder.
\end{abstract}

Keywords: Semantics, Psychoanalysis, Criminal Investigation, Independent Research

\section{Introduction}

On the occasion of an exposition about the "criminal investigation" I was questioned by the late professor Gheorghe Scripcaru, "please tell me, what is the criminal investigation looking for on the shelves of sciences". I replied, "EVERYTHING."

Professor Gheorghe Scripcaru replied, I also had an answer, but yours is complete. If you think like this and you consistently apply this thinking, you will surely become the promoter of the introduction of hemistemology in the investigation of criminal actions. The encouragement of Professor Gheorghe Scripcaru had a special effect, since then I am talking about "The Science of Criminal Investigation, a science that seeks truths in science. Presenting this form $\mathrm{Mr}$. Prof. Emilian Stancu i received the smile and the congratulatory hand. These assurances, coming from two eminent guarantors of science, were enough for me.

Of course, the title of this paper is about RENE 
DE'SCARTES, A Discourse on the Method of Conducting Our Reason Well and Seeking the Truth in Science. I have attached the famous Cartesian formulation to this discourse on the discovery of unknown truths, hidden truths, and truths affected by error or subjectivism.

We have adopted and reserved the strategy of searching for favorable evidence in science, for the situations in which the evidentiary procedures applied for obtaining the means of proof, and the evidence obtained itself reflect states of tension or the existence of several meanings or a confusing meaning. The strategy aims at an objective way of information that can only be achieved by using science.

The remark of the unknown truths, of the hidden ones and of the truths affected by error or subjectivism follows from the study of the notifications made in the stages of the criminal investigation procedure, respectively: the stage of the crime and criminal study from a phenomenological point of view (finding procedure); the stage of the study of the crime and the criminal from a legal point of view, (the procedure of procuring the means of proof); the contradictory study stage of the crime and the criminal (the procedure before the judge). We do not believe, with certainty, the writings have a voice and whisper to us, if we listen to the appreciation and exhortation of the late professor Ionel Tanoviceanu.

"The system of disciplines whose object is the study of crime and criminality as natural, social and legal phenomena is given the name of criminal science. This term is considered more proper and more accurate than the term criminal science, which has the defect of expressing only the repressive side which represents a small part of the total forensic problems. The field of criminal science being quite vast, and its problems involving multiple specialties, it is difficult for someone to possess complete and perfect knowledge of all the disciplines that make it up. That is why no one will claim that a criminal criminalist is at the same time a perfect anthropologist, a perfect sociologist, etc.; but what will be required of him will be to keep in constant contact with all the disciplines that make up criminal science and to use their final results obtained".

In essence, our strategy concerns operations of knowing the feelings, thinking and activities of procedural subjects, both litigants and justices. We capitalize on the content of the means of proof based on the results definitively obtained by the science of semantics and psychoanalysis, relating to the knowledge of the science of logic associated with the exact sciences. We cannot expose a method regarding this kind of knowledge, because each case has its individuality, an individuality that urges us to a continuous search for truth in science.

I present some excerpts from our research reports.

\section{Research Report Extracts}

\subsection{Object of the Research - Characterization of the Function of the M. A. Dialogue. - N. R.}

In addition to its function of reproducing the conversation, dialogue is also a means of characterization. He gives the interlocutors the opportunity to present themselves, by what they say or by the way they express themselves. [1]

1. In the present case, we note that M. A., knowing the circumstance of the environmental registration, adapts his language to the purpose of the communication situation, respectively the consolidation of the affirmative content of the statements and denunciations formulated by him. In order to produce this effect, the mentioned dialogue includes the repeated mention of the previous statements regarding B. M. C., D. C. and D. GHE.

Table 1. Function of the Recorded Dialogue.

\begin{tabular}{lll}
\hline TOTAL REPLIES 307Interrogative $-\mathbf{8 6}$ & RELATIVE TOB. M. C. & RELATIVE LAD. C \\
\hline N. V. R.-152 & & RELATIVE TOD. GHE. \\
M. A.-155 & Bigiu-22 / Cristi-19 & 5 \\
\hline
\end{tabular}

Communication intentions are relevant due to the fact that using a rhetorical question in discourse involves approaching a manipulation strategy. The rhetorical question relies on what the question normally entails, the demand for an answer, and its (apparent) freedom of choice. Pretending that this freedom of answer is given to the interlocutor through the very syntactic structure used, the rhetorical question suggests and even directs the discourse in the desired direction.

Its role is to make known to the interlocutor the attitude he should adopt in that situation by virtue of past facts which are mentioned as arguments in support of the conclusion which the rhetorical question implicitly expresses.

2. If we bring into question the statement made by Minister D. C. [statement dated.....] regarding the kinship relationship between M. A. and N. V. R. and that the latter "fell more and more under the influence of the former"....... we note that the statement has an objective character, deduced by D. C. and confirmed by the semantic connotations of the environmental dialogue in which the interlocutors mutually and consistently confirm their remarks.

We are therefore faced with a reconstituted dialogue with a reciprocal confirmatory connotation, the purpose of which is to consolidate by way of corroborating previous statements, wishing that they can no longer be vitiated by the contexts of the true factual situation.

3. A significant problem of the dialogue is that the two interlocutors interrupt each other in the act of communication, which can be translated as the desire to actively participate in the purpose of the communication situation, respectively, strengthening the content of statements and denunciations made by them. at BMC, DC and D. G.

CONCLUSION 
The dialogue we are referring to [M. A. - N. V. R.] was preconstituted for the purpose of establishing an evidentiary proceeding the content of which to be corroborated with the statements of M. A. and denunciations of the case. From this perspective it can be inferred that the mentioned evidentiary procedure [the written reproduction of the environmental dialogue, carried out on..... between the named M. A. with N. V. R.] is affected by uptake.

\subsection{Procurement of the Information Element}

OBJECT OF THE RESEARCH - Procurement of the information element likely to indicate the existence / non-existence of incriminating remarks related to the crime of influence peddling.

Table 2. Minutes of written reproduction of the environmental dialogue.

\begin{tabular}{lrr}
\hline $\begin{array}{l}\text { DATE OF THE ENVIRONMENTAL DIALOGUEDATE } \\
\text { WRITTEN PLAYBACK }\end{array}$ & DATE WRITTEN PLAYBACK & Interlocutor \\
\hline 11.09 .2014 & NO. REPLIES & P. J. \\
\hline
\end{tabular}

FINDINGS: ART. 291 Trafficking in influence (1).

HYPOTHESIS - Claiming, receiving or accepting the promise of money or other benefits, directly or indirectly, for oneself or for another,......... CONDITIONS -.... committed by a person who has influence or leaves to be believed to have influence over a civil servant and to promise to cause him to perform, not to perform, to hasten or delay the performance of an act which falls within his duties or to perform an act contrary to those duties, is punishable by imprisonment from 2 to 7 years. [2]

MATERIAL ELEMENT - Claiming, receiving or accepting the promise of money or other benefits.

Table 3. Key phrases.

\begin{tabular}{lll}
\hline NORMAL LETTER & SYNONYMY & ANTONYMY \\
\hline CLAIM & He insistently asks for one thing & To ask $\neq$ to offer \\
I claimed & I asked & I offered \\
I claimed you & I asked you & I offered you \\
You claimed & you asked & A primi da a da \\
they claimed & they demanded & I gave \\
RECEIVING & To get, to get & I gave it to you \\
I received & he gave me & they gave me \\
you got & You gave it to me & To accept $\neq$ to refuse, \\
they received & I took & \\
ACCEPT & He agrees with...; you agree to...; admit.... & \\
I accepted & I accepted & I agreed \\
you accepted & I agreed & \\
they agreed &
\end{tabular}

CONDITION, with reference to the person who has influence or suggests that he has influence over a civil servant and who promises.

Table 4. Key phrases.

\begin{tabular}{lll}
\hline NORMAL LETTER & SYNONYMY & ANTONYMY \\
\hline $\begin{array}{l}\text { Influence } \\
\text { promise }\end{array}$ & power, authority, hardening & \\
\hline
\end{tabular}

The procurement of the information element likely to indicate the existence / non-existence in the minutes of some incriminating remarks relative to the crime of influence peddling is to be carried out through the following operations:

a) the technical editing in the WORD program of the content of the minutes of the written reproduction of the environmental dialogue carried out on 11.09.2014 between PoenaruJănică and IacobSorin Ion, strictly respecting the content and the punctuation;

b) the comparative examination of the photocopies of the minutes of reproduction in written form with their technically edited content;

c) pre-establishment of the key expressions to be used for the computer search operation;

d) the use of the WORD $\rightarrow$ EDIT $\rightarrow$ FIND program, respectively of the immediate and indisputable possibility regarding the demonstration of the existence / non-existence in the minutes of rendering in written form the registered dialogue of the pre-established key expressions.

\section{Conclusion}

The research applied on the basis of the search criteria established following the analysis of the legal norm (art. Art. $291 \mathrm{Cp}$ ) indicates that the computer program WORD EDIT

FIND establishes that in the minutes of the written reproduction of the environmental dialogue. 2014 between PJ and ISI There were NO expressions [replicas] with incriminating content uttered by P. J. relating to the crime of trafficking in influence ${ }^{1}$.

1 HYPOTHESIS - claiming, receiving or accepting the promise of money or other 
Table 5. Key phrases.

\begin{tabular}{lll}
\hline $\begin{array}{l}\text { KEY EXPRESSIONS } \\
\text { (search criteria) }\end{array}$ & WORD ANSWER & $\begin{array}{l}\text { FOUND } \\
\text { EXPRESSION }\end{array}$ \\
\hline I claimed & $\begin{array}{l}\text { Word found no items } \\
\text { matching this criteria }\end{array}$ \\
I claimed you & $\begin{array}{l}\text { Word found no items } \\
\text { matching this criteria }\end{array}$ \\
\hline
\end{tabular}

CONDITIONS - a person who has influence or lets himself be believed to have influence..... and who promises.

Table 6. Key phrases.

\begin{tabular}{lll}
\hline $\begin{array}{l}\text { KEY EXPRESSIONS } \\
\text { (search criteria) }\end{array}$ & WORD ANSWER & $\begin{array}{l}\text { FOUND } \\
\text { EXPRESSION }\end{array}$ \\
\hline Influence & $\begin{array}{l}\text { Word found no items } \\
\text { matching this criteria }\end{array}$ & \\
Power & $\begin{array}{l}\text { Word found no items } \\
\text { matching this criteria }\end{array}$ & \\
\hline
\end{tabular}

\subsection{Equivalence as an Ethical Principle}

OBJECT OF RESEARCH - equivalence regarding equality as an ethical principle

Table 7. Equivalence as an Ethical Principle.

I. G.

LOGIC OF STORIES

I had nothing personal with any of the

defendants in the case, but as a simple citizen I

do not admit to seeing how the Romanian state is robbed.

This is how I appreciated the procedure at that moment, given the fact that I considered that if I had directly involved Vişan, things would have gone in a direction that I could not have controlled.

I appreciated that being difficult to fight with the defendant Ceteraş who has very large sums of money and who took large areas of land throughout the country, it would have been difficult for me, as my personal and family interests would have been affected. I have children.

Table 8. Equivalence as an Ethical Principle.

\begin{tabular}{|c|c|}
\hline I. G. & Witness V. J. \\
\hline $\begin{array}{l}\text { The named V. explained the things I } \\
\text { explained earlier, he did it in a broad } \\
\text { framework in directing, he did not give me } \\
\text { this confidence personally. } \\
\text { I mention that the wide circle I referred to } \\
\text { refers to colleagues not in the actual } \\
\text { direction. } \\
\text { I made this statement due to the documents } \\
\text { in the possession of the National Authority } \\
\text { that led to this conclusion as well as } \\
\text { because I learned from the named J. V. by } \\
\text { dividing these sums of money. } \\
\text { He didn't tell me how he knew about these } \\
\text { issues, nor did I ask him, primarily because } \\
\text { I was in a smaller circle and it didn't seem } \\
\text { normal for me to ask. In fact, Vişan Jean } \\
\text { stated that he cannot say more because it } \\
\text { would endanger his personal security as }\end{array}$ & $\begin{array}{l}\text { "Everything I know, I know } \\
\text { from rumors... from public } \\
\text { rumor I learned about the } \\
\text { existence of a transaction" } \\
\text { "Starting from these rumors } \\
\text { with a lot of imagination, a } \\
\text { little manipulation, the idea } \\
\text { was outlined..." } \\
\text { "I don't know why my } \\
\text { person was called as a } \\
\text { witness, it's possible that the } \\
\text { undercover witness referred } \\
\text { to me." } \\
\text { "I am not sure that what is } \\
\text { being discussed and } \\
\text { mentioned is true...: } \\
\text { ZVONISTICĂ s. F. Sg. } \\
\text { Activity of creating, }\end{array}$ \\
\hline
\end{tabular}

benefits.

\begin{tabular}{|c|c|}
\hline I. G. & Witness V. J. \\
\hline $\begin{array}{l}\text { well as that of his family. No, this was also } \\
\text { supported by the so-called V. J. }\end{array}$ & $\begin{array}{l}\text { launching and spreading } \\
\text { false information. }\end{array}$ \\
\hline
\end{tabular}

IF looking for equivalence regarding equality as an ethical principle, we were forced to use the symbol $\neq$ (not equal to). THEN, looking for equality, I found the inequality, and I found that the statement is a report in which the witness reproduces aspects stored in memory during the criminal investigation, not before, and that the source of the allegations is rumor, or an activity of creation, launch and dissemination of false information.

\subsection{The Role of Empathy in Interprofessional Reasons}

OBJECT OF RESEARCH - The characteristic of communications from the perspective of empathy

We notice the characteristic of NECESSITY, the adoption of the empathic strategy relative to the professional functionality that is based on some universal constants, fixed and very precise, and that can be offered from the one who leads to those who execute, of course in a conditionality ${ }^{2}$ framework.

Table 9. Discussions in the environment.

\begin{tabular}{lll}
\hline $\begin{array}{l}\text { THE ONE WHO } \\
\text { LEADS }\end{array}$ & EXECUTOR 1 & EXECUTOR 2 \\
\hline & $\begin{array}{l}\text { I was saying in the first } \\
\text { phase to put in, to have put } \\
\text { in their phones, if... }\end{array}$ & \\
$\begin{array}{l}\text { Lu Cochinu yes, } \\
\text { luRămotină no. }\end{array}$ & & $\begin{array}{l}\text { Rămotină helped } \\
\text { us in a very... }\end{array}$ \\
\hline
\end{tabular}

The way in which the leader, together with the performers, chose the strategies to follow is faithfully reproduced by the first record, and the second renders the conditionality reflected by the empathic strategy of the leader, more precisely the knowledge of the need implicitly manifested by the performers. to be treated empathetically.

The use of language, phrases and expressions consecrated by interprofessional communication is made from the perspective of achieving special performances, of above average level, which requires a constant and deep need, wide coverage and intensity of empathy. [4]

It should be noted that the evidence of the case indicates that the empathy of prosecutor T. O. C. "his ability to transpose abroad" is strictly related to the oratory field (communication to police interlocutors,) without being followed by the materialization of communication through preparatory acts, or documents indicating an attempt or consummation of the crime of abuse of office. So we are going to understand that we are in front of an event with justification in the field of professional performance.

\section{CONCLUSIONS}

The content of the audio and video recordings indicates that T. O. C. knew and used the three types of communication as assets derived from the professional realities he was trying to

2 Discussions in the environment, in the professional office. 
consolidate ${ }^{3}$.

The dialogues carried out by prosecutor T. O. C. with police officers from the I. P. J..... are justified in terms of interprofessional reasons. Because the strategy of empathy is a concept established by the Science of Criminal Investigation Procedure. Consequently, the phenomena of containment and interpretation in the prosecution office can NOT be taken into account.

\subsection{Investigation of Witness and Testimony}

OBJECT OF THE RESEARCH - the personality of the witness.

Table 10. Investigation of Witness and Testimony.

\begin{tabular}{|c|c|c|}
\hline $\begin{array}{l}\text { PAGE } \\
\text { PARAGRAPH }\end{array}$ & CONTEXT EXAMINED & $\begin{array}{l}\text { PSYCHANALYTICAL } \\
\text { INTERPRETATION }\end{array}$ \\
\hline P. 1 al. 2 & $\begin{array}{l}\text { He asked me for a working } \\
\text { meeting }\end{array}$ & $\begin{array}{l}\text {.... working meeting also } \\
\text { involves a next meeting } \\
\text { (so, expect information } \\
\text { from the person who } \\
\text { proposed the meeting) }\end{array}$ \\
\hline P. 1 al. 3 & $\begin{array}{l}\ldots . \text { all the details of the } \\
\text { discussion...... was recorded } \\
\text { with my own means of } \\
\text { recording } \\
\ldots . \text { I was a computer scientist } \\
\text { and I had a passion for } \\
\text { making "cineverite" } \\
\text { recordings, and there was } \\
\text { also a playful pleasure in } \\
\text { manipulating these devices }{ }^{4} \text {. }\end{array}$ & $\begin{array}{l}\text { He takes action } \\
\text { Intellectual ability, } \\
\text { technical and philosophical } \\
\text { culture, pragmatic } \\
\text { reasoning, judgment of } \\
\text { taste, sense of reality and } \\
\text { ease. } \\
\text { He thinks the investigation } \\
\text { should be a "free play of } \\
\text { imagination and intellect." } \\
\text { He is disappointed.[5] }\end{array}$ \\
\hline P. 1 al. 4 & $\begin{array}{l}\ldots \text { my interest, to get rid of } \\
\text { the problem of these lands... }\end{array}$ & $\begin{array}{l}\text { It externalized the } \\
\text { eventuality of the sale of } \\
\text { the disputed rights BUT..... }\end{array}$ \\
\hline P. 1 al. 5 & $\begin{array}{l}\text {... something that didn't suit } \\
\text { me.... }\end{array}$ & $\begin{array}{l}\text {.... prospects the } \\
\text { possibility of an advantage, } \\
\text { a success, a profit }\end{array}$ \\
\hline P. 2 al. 1 & $\begin{array}{l}\text {.... to talk to those from the } \\
\text { County Commission and to } \\
\text { suggest "to make it softer" } \\
\text { with the processes. I mention } \\
\text { that I refused this and the } \\
\text { discussion ended. }\end{array}$ & $\begin{array}{l}\text { Transmite faptul că, nici } \\
\text { unul din interlocutori nu } \\
\text { s-a angajat la } \\
\text { compromisuri }\end{array}$ \\
\hline P. 2 al. 2 & $\begin{array}{l}\text {.... when he contacted me he } \\
\text { did not show seriousness but }\end{array}$ & $\begin{array}{l}\text { He appreciates that the } \\
\text { dialogue did not enjoy }\end{array}$ \\
\hline
\end{tabular}

3 See the model developed by Dr. A. Mehrabian, in the '70s, - Verbal communication is only one aspect of the act of communication, important but not defining !. This represents a percentage of only $7 \%$ of communication, to which is added $38 \%$ paraverbal communication (through vocal features that accompany the word, such as: voice characteristics, intensity, rhythm, speech rate, intonation, etc.) and $55 \%$ communication nonverbal. (by signs directly related to posture, movement, gestures, facial expressions, appearance.)

4Ciné-veritésn [At: DEX2 / V: cinema- / P: sineverite / E: frciné-vérité] A genre of cinematography that attaches great importance to realistic elements and avoids artistic effects, often using unprofessional actors.

ludic, -ă adj. Which has the character of a game; which is funny, sprinting. Regarding the game; game specific. (about activities, artistic manifestations, etc.) in which the game prevails, the release of the fantasy similar to childhood. (subst. n.) Uses play in theater. Ext. Which is without practical purpose. pl. -ci, -ce. playful the pleasure communicated by the judgment of taste and which comes from a "free play of imagination and intellect" (Imm. K ant, "Critique of the faculty of judgment").

\begin{tabular}{lll}
\hline $\begin{array}{l}\text { PAGE } \\
\text { PARAGRAPH }\end{array}$ & CONTEXT EXAMINED & $\begin{array}{l}\text { PSYCHANALYTICAL } \\
\text { INTERPRETATION }\end{array}$ \\
\hline & $\begin{array}{l}\text { it was more of a discussion of } \\
\text { groping or trying } \\
\text { …... then acted in a } \\
\text { speculative manner } \\
\text { (interlocutor) }\end{array}$ & $\begin{array}{l}\text { importance, significance, } \\
\text { depth }\end{array}$ \\
P. 2 al. 3 & He is convinced of this \\
\hline
\end{tabular}

The witness listened to and selected the statements of the interlocutors, appreciating them as "frivolous". Consequently, it did NOT form "justified true beliefs."

Table 11. Answers to questions.

\begin{tabular}{|c|c|}
\hline TONE & $\begin{array}{l}\text { CHARACTER } \\
\text { PROPERTIES }\end{array}$ \\
\hline $\begin{array}{l}\text { Yes, it's true and I keep the statements I gave to } \\
\text { the prosecutor's office but I show..... I took it } \\
\text { rather as a joke } \\
\text { I think it was of general knowledge;.... But } \\
\text { obviously it was a copy. } \\
\text {... there was no discussion about concrete } \\
\text { money values either in terms of c / val. works; I } \\
\text { didn't have a good enough financial situation..... } \\
\text { I was interested in selling the disputed rights; } \\
\text { Also the answer is no, no amount has been } \\
\text { discussed. } \\
\text { Yes, there were discussions but free, in threes, } \\
\text { carried out by all three face to face, } \\
\text { Definitely not / No, by no means, } \\
\text { Did I file a complaint against Prosecutor Nica? } \\
\text { many errors persisted,... I complained to the } \\
\text { hierarchically superior prosecutor } \\
\text { I can't be one hundred percent sure of these } \\
\text { things. } \\
\text { At the Brasov Court of Appeal I did not } \\
\text { mention anything because no one asked me }\end{array}$ & $\begin{array}{l}\text { The tone of the answers } \\
\text { indicates the } \\
\text { organization of ideas in } \\
\text { relation to a center of } \\
\text { principles }{ }^{5} \\
\text { He is attentive to the } \\
\text { wording, the nuance, } \\
\text { the questions } \\
\text { He can't stand } \\
\text { ignorance } \\
\text { He doesn't always aim } \\
\text { to win } \\
\text { He knows how to listen } \\
\text { He doesn't need } \\
\text { attention } \\
\text { Fearless } \\
\text { He is not very attentive } \\
\text { to insignificant things } \\
\text { He can't find an excuse }\end{array}$ \\
\hline
\end{tabular}

The witness knows and defines the notion of personality as a reflectivity of the purposes and effects it causes. Regarding the notion of purpose, it accepts the definition in the sense of purpose, purpose, $\mathrm{NO}$ and target. He appeals to his qualitative existence in order to avoid any shade of irony towards his social status. (Print) He considers consciousness as a feeling that man has about the morality of his actions.

The testimonies are characterized by the certainty and assumption of the statements, without being contradicted by any of the existing means of proof in the case file.

\section{CONCLUSION}

If we consider the center of interest of the hearing of the witness, respectively, his knowledge about the incriminated intentions and actions, we notice that the witness did NOT have knowledge (of......), was NOT informed about........) NOT getting acquainted with........ NOT knowing the aspects from all points of view; He did NOT care about obtaining such information. Consequently witness S. P. G. failing to form true justified convictions could NOT convey, did NOT provide evidence that could allege criminalization of the defendants.

\subsection{Strengthening the Testimony of Good Faith}

OBJECT OF THE RESEARCH - Analysis of the testimony.

5 Tone s. f. 2. Dominant feature, specific note of a writing. 
As individuals, witnesses can be divided into two categories: witnesses in good faith and witnesses in bad faith. Those in bad faith are those who are determined to bear false witness, either out of material interests being bribed or out of spiritual interests - being friends or enemies of the parties.

Every testimony has a double aspect: subjective and objective. There is always a certain direction of research on the psychological phenomena that accompany the formation of judicial testimony, given certain attributes regarding testimony and witnesses, because even the testimony of good faith can be stalked by falsity and a certain relativism due to some sensory failures. [3]

The psychic processes involved in the acquisition of information by the witness are, first of all, sensations and perceptions, then representations and memory.

In the analyzed case, the sensation and perception processes of the witness are those based on visual and auditory analyzers. Naturally, the witness appreciates that the visual testimony is more important than the auditory one.

What he saw is relevant and devoid of subjectivism, even if the quality of this information was influenced by objective conditions, respectively, the distance from the place of the event and the light conditions ${ }^{6}$.

Looking from the perspective of the psychoanalytic theory of personality we can highlight the way in which the witness managed to establish a balance between various aspects of his personality, respectively, the manner of processing the information collected that allows positive answers to questions.

Lawyer question: If you weren't threatened, why are you afraid to say what you heard?

Answer: It is well known why I do not want to make statements on this issue, which I consider irrelevant and subjective anyway.

Lawyer question: Did you hear the name of the person who killed D. P.?

Answer: Yes, I heard, but I can say that it is not the person in the box, respectively, V. C.

By asking the lawyer the question "If you have not been threatened, why are you afraid to say what you have heard? "The witness is pushed on a field of testing the psychic valences. Aware of her situation, the witness manages to

6Declaration of 28.10. 2015 - I maintain the statement given at the criminal investigation. I show that I'm next door to Durac Petrica. Between our houses there is an alley and a vacant lot. My house is at a distance of $50 \mathrm{~m}$ from the street.

In the evening of 04.01.2015, while I was at the shops with Gore Dorina Giorgiana, I saw a lot of people, I think about $20 \ldots$, some of them in front of the yard of the Durac family home, and the rest..... I have heard Durac's wife shouting "don't kill him anymore" my husband called 112. I can't say who the people who came across the Durac family are because I don't know them. I show that in front of the store there was street lighting, but the Durac family lives in an alley, and there is no public lighting. I look like the Durac family had the light in the yard. My store is located about 30-50 m from the yard of the Durac family home. I have never seen the defendant in my life. It's the first time I've seen him.

I show that I am afraid to say what I heard immediately after the incident because they can come at me at any time, respectively I mean the people who entered the Durac family home, so I want to declare only what I saw. I have not been threatened so far by anyone and I have not been asked to give statements in one way or another. provide an answer that is as consistent in terms of significance as it is justified and mentally balanced. Thus, the answer: "It is known why I do not want to make statements on these issues, which I consider irrelevant and subjective anyway." denotes: 1) the witness's refusal to enter the lawyer's game (stating that: "It is known what the reason is"); 2) awareness that one's own statements on issues stated for hearing would be unnecessary ("consider I consider them irrelevant and subjective anyway.")

This way of processing the information collected as well as the answers provided indicates that, although the witness's personality is subject to censorship, it manages to remove the prohibitions, acquiring moral responsibilities and obligations by providing an answer derived from corroborating the facts heard and perceived by own visual and auditory senses (from his perspective a relevant and non-subjective response), which serves to create opposition to the situation of the person in the speaker "Yes, I heard, but I can say that he is not the person in the speaker, respectively, V. C. ${ }^{7}$.

CONCLUSIONS - The testimony cannot be stalked by falsehood, therefore it is in good faith.

The witness responds cautiously, but unequivocally acknowledges that the person in the box (V. C.) is NOT the person who has to bear the consequences of the crime of murder.

The credibility of the statement is strengthened by facts and circumstances that indicate the positioning of the testimony in terms of visual and auditory perception, respectively:

The land on which the store is built is located at a distance of approx. $50 \mathrm{~m}$ from the place of the event and is surrounded by a mesh fence that allows good visibility to the gates of the victim's home.

The group of attackers, accompanied by the group of curious people, passed in front of the store both on arrival and departure. People in the group of the curious commented on the facts they witnessed right in front of the store, together with the witness.

\subsection{Exploratory Observations from the Perspective Art. 101 Paragraph. (3) C. P.}

At the beginning of the conversation, the main police officer F. A. M. informs C. M. about receiving the result of the laboratory analyzes regarding P. M.

The main police officer F. A. M., leans towards the side compartment of the work table from where he takes several A4 papers that he browses.

F A M: This one came to him... the one from I. M. L came to him...

C M: Result from... drink?!

F A M:... drink, yes... 1 and 12 .

C M: A lot of them?...

F A M:..1 and 12.. at the first test and at the second 0.97 . Was decreasing. He probably drank in the morning, I don't know?

7PUTEÁ pot, vb. II. Tranz. (followed by a verb in the subjunctive or in the infinitive) To have the moral power to say; To have the right to say; To be indicated, accordingly, to be good to..., to be the case to...; to deserve, to fall to say; Don't be afraid to say. 
C M: He said he drank at night... at night, I don't know what he's saying... he's in the hospital now, he's bad luck!

The main police officer F. A. M. presented to the dialogue partner (C. M.) the data from the toxicological analysis bulletin, no. 2496 / 23.10.2019 regarding P. M., respectively, the values of the alcohol level at the moments of the first and the second harvest, NOT the value of the blood alcohol level at the moment with legal relevance (value unknown by the agent).

In order to know the value of blood alcohol at the time of legal relevance, it was necessary to present the data of the case to the National Institute of Forensic Medicine, in order to establish the phase of alcohol (elimination or absorption) at the time of legal relevance (time of occurrence) and this basis to proceed, as the case may be, to the forensic expertise aiming at the retroactive estimation of the blood alcohol level or the assessment of the blood alcohol level in relation to the limit provided by law as a crime, to communicate the finding of the judicial body. 2015 issued by the Superior Council of Forensic Medicine. The expert procedure was not performed, moreover, no estimation of the blood alcohol level was performed. [6]

According to the known data algorithm, it is very possible that the value of alcohol at the time of legal relevance was below the limit provided for the finding of the crime, meaning that the main police officer had to refrain from using hypothetical data during the investigation ${ }^{8}$.

Table 12. Truth table.

\begin{tabular}{|c|c|c|c|}
\hline $\begin{array}{l}\text { Interval } \\
(\mathrm{min})\end{array}$ & Time & Alcohol & \\
\hline 0 & & $?$ & $\begin{array}{l}\text { Circumstances of alcohol consumption - } \\
\text { unknown }\end{array}$ \\
\hline 5 & & & \\
\hline 30 & $11: 30$ & & The moment with legal relevance \\
\hline 65 & 12:05 & 0.7 & $\begin{array}{l}\text { Ethyl test - indicative information } \\
\text { regarding the collection / non-collection of } \\
\text { biological samples. }\end{array}$ \\
\hline 140 & $13: 20$ & 1.12 & First harvest \\
\hline 200 & $14: 20$ & 0.97 & Second harvest \\
\hline
\end{tabular}

MATERIAL ELEMENTS (promise - offer - giving money) FAM: Yes. no... (unintelligible)... I have to. to take a statement on this, a file came to me and no... we have... we have the driving of a vehicle under the influence of alcohol,

8 The judicial body has the obligation: TO VERIFY and objectify the act of finding by reporting to the data entered in the emergency file of the ambulance service, hospital treatment register, $\mathrm{p}-\mathrm{v}$ for collecting biological samples, statements of persons; TO OBJECTIVE the consumption declaration, by referring to the data entered in the report of collection of biological samples, declarations of persons, investigative acts, clinical examination sheet (annex to $\mathrm{p}-\mathrm{v}$ of collection of biological samples); and TO SIMULATE the future expert operation for different variants reflected by the case data. During the analysis, the trinomial of errors unknown - subjectivism can be established and corrected, thus moving from the possibility of knowledge to the knowledge itself controllable with the help of scientific means

In an immediate (information) approach, one can use the truth table of a logical function, more precisely a list of all the points of the definition set, for each of them specifying the value of the function.

Logical functions have logical values sometimes called truth values ("true" and "false"), hence the name truth table. (Illustration) [7].

See in this sense JURIDICE.RO "Analysis of the necessity and usefulness of disposing the expertise for the retroactive estimation of blood alcohol" 27.03.2019. uh... unregistered, you know we also discussed last time and entrusting a vehicle.

The phrase "entrusting a vehicle" draws C. M.'s attention to the possibility of assigning the entrustment of the vehicle.

The DETERMINED RESOLUTION REACTION appears

Table 13. Determined Resolution Response.

\begin{tabular}{|c|c|}
\hline COMMUNICATION & $\begin{array}{l}\text { SEMANTICS AND PSYCHANALYSIS } \\
\text { OF COMMUNICATION }\end{array}$ \\
\hline $\begin{array}{l}\text { C M: Well, what, I entrusted } \\
\text { it to him or... we can't to... } \\
\text { (unintelligible) him... finish } \\
\text { the file? } \\
\text { F A M: You realize... How? } \\
\text { C M: We can't... } \\
\text { F A M: Well, how can we? } \\
\text { C M: The proposal to the } \\
\text { prosecutor or to those from } \\
\text { here also comes from you... } \\
\text { F A M: Well, leave... } \\
\text { C M: Not for nothing, I give } \\
\text { you a hundred million } \\
\text { F A M: How much? } \\
\text { C M: One hundred } \\
\text { million... } \\
\text { F A M: That's it?! }\end{array}$ & $\begin{array}{l}\text { CM: Well what, I entrusted it to him or...... } \\
\text { (incriminates me!) Well what - expresses } \\
\text { reserve, hesitation IMMEDIATE } \\
\text { REACTION }{ }^{9} . . \text { we can't to.. (unintelligible) } \\
\text { 1. do we finish the file? } \\
\text { Emphasizing the meaning of } \\
\text { communication completed by rhetorical } \\
\text { question } \\
\text { disconcert } \\
\text { Well, how can we? How: Strengthens the } \\
\text { rhetorical question, } \\
\text { Communication for yourself / wants } \\
\text { money!!! } \\
\text { Well, leave... Strengthen an exhortation, but } \\
\text { leave here (indicate the possibility) } \\
\text { CHALLENGED PROMISE } \\
\text { rechallenge } \\
\text { PROVIDED OFFER } \\
\text { Rechallenge }\end{array}$ \\
\hline
\end{tabular}

Table 14. Insistance of fulfilling the three material elements.

\begin{tabular}{|c|c|}
\hline COMMUNICATION & $\begin{array}{l}\text { SEMANTICS AND } \\
\text { PSYCHANALYSIS OF } \\
\text { COMMUNICATION }\end{array}$ \\
\hline $\begin{array}{l}\text { F A M: Well, how do we do it? } \\
\text { C M: I'll leave you somewhere... } \\
\text { somewhere... whoever you want... I'll get } \\
\text { down and leave you there... I'll give you to } \\
\text { someone, to... } \\
\text { F A M: Unintelligible. } \\
\text { CM: Think it'sbonlav and those... let me die if } \\
\text { you don't... you're doing a good deed... look, } \\
\text { we also have children... I've looked for her } \\
\text { sometimes, I've left her like this since me and } \\
\text { those especially. let's say... unintelligible... if he } \\
\text { did something, he would kill them in his head, } \\
\text { he did... he didn't do... fuck him... yes... } \\
\text { F A M: I'm waiting for you here while I'm } \\
\text { doing something? } \\
\text { C M: Come on, I'm going now to see... if I } \\
\text { bring you } 50 \text { now and } 50 \text { tomorrow? } \\
\text { F A M: How do you say... unintelligible... }\end{array}$ & $\begin{array}{l}\text { WELL adv. Familiar, in } \\
\text { competition with then. } \\
\text { Usually reinforced by } \\
\text { "yes", "of course", "that", } \\
\text { it expresses a statement or } \\
\text { approval } \\
\text { THERE WAS NO } \\
\text { RESOLUTION OF THE } \\
\text { BEHAVIOR BEFORE } \\
\text { THE CHALLENGE }{ }^{10} \text {. }\end{array}$ \\
\hline
\end{tabular}

9 On this relationship (objective, normal, natural, common) there is always a chain of thought, which includes a flow oriented to goals, ideas and associations that lead to a conclusion oriented to reality or vice versa. The process of perceiving tones is very important. We ensure this process by listening to the testimony of the sound signals, simultaneously with the reading of the playback in written form.

10 The current doctrine notes and states "there is a challenge on the part of state bodies when the agents involved are not limited to the examination of a purely passive manner of illicit activity, but exert an influence on the person concerned to incite him to commit a crime that would not otherwise has been committed, in order to make it possible to establish the crime, ie to obtain evidence and to prosecute" (Ramanauskas, Eurofinacom v. France). (ICCJ, Criminal Section, Decision No. $65 \mathrm{~A} / 2015)$. 


\section{CONCLUSIONS}

The use of hypothetical data in argumentation, together with the adaptation of the whistleblower's rhetoric to a scenario, are sufficient elements to indicate that the main police officer F. A. M. did not limit himself to the purely passive examination of the illicit activity, but exercised over the so-called C. M. had an influence that would incite him to commit the crime that would not otherwise have been committed.

SO, according to art. 102 N. C. P. the means of proof entitled "minutes of replaying the conversations recorded in the environment aiming at replaying the conversations carried out on 17.06 .2020 by the main police officer F. M. A. and C. M., is punished with nullity.

\subsection{Reflectivity of the Cryptographic Text}

OBJECT OF THE RESEARCH - The reflectivity of the cryptographic or slang text

Since the transcription of the conversations is not the object of the forensic expertise of the voice and speech, the minutes regarding the written reproduction of the dialogues are to be verified from the semantic perspective.

The semantic perspective allows the verification from the point of view of possible errors or subjectivism manifested in the procedure of rendering in written form the recorded dialogue, as well as the interpretation of the dialogue context and its particularization regarding the establishment of objective and subjective elements (suggestion and capture) $)^{11}$.

11 Legal (judicial) linguistics, or language and law, is the implementation of linguistic knowledge in the context of law, investigation, trial and judicia procedure. It is a branch of applied linguistics. [6]

In Romania, forensic linguistics has already become a challenge of fundamental research, following the appearance of applied research reports conducted by the Center for Research in Applied Legal Ethics Rm.Sarat. [see case study, next page] According to Western literature, there are mainly three areas of work of linguists working in forensic contexts: Understanding the language of written law; understanding the use of language in forensic and judicial proceedings; providing linguistic evidence.

Use of linguistic evidence in judicial proceedings: Identification of the author; legal stylistics; speech analysis; dialectology; Legal phonetics; linguistic imprint

The discipline of legal linguistics is not homogeneous and involves a number of experts and researchers in different areas of the field. The term forensic linguistics first appeared in 1968, when Jan Svartvik, a professor of linguistics, used it in an analysis of Timothy John Evans' statements.

Legal linguistics emerged when a team of investigators questioned the authenticity of police statements. At the time, the usual police procedure for taking statements from suspects was dictation, so that they would fit into a certain pattern, rather than the suspect's own words. Witness statements were rarely made in a coherent or orderly manner and contained much speculation. The dictation of the statement was often too quick, so many important details were left out. In the 1980s, Australian linguists discussed the application of linguistics and sociolinguistics to legal issues. They found that an expression such as "the same language" could be interpreted in various ways. Aboriginal people have their own understanding and use of the "English language", which may differ from the official version of the English language. Thus, the aborigines used in their statements their own expressions based on their own culture and traditions.

The study of language is applied to a wide range of legal texts. This study may include text types and forms of analysis. Any text or element of spoken language can potentially be a legal text, when used in a legal or criminal context.

Among other things, this field examines the language used in the presentation of evidence, court sentences, police testimony in court, interrogation, statements, etc.
It also allows for clarifications when the style of verbal communication that does not enjoy clarity, simplicity, naturalness and correctness, when the words are not appropriate to the ideas they express, are not logically linked to be understood. [8]

Table 15. Cryptographic or slang text reflectivity.

\begin{tabular}{|c|c|c|}
\hline DATE / CODE & INTERLOCUTOR & REPLIES \\
\hline 0060405_201641 & $\begin{array}{l}\text { Unknown } \\
\text { X1 } \\
\text { X2 }\end{array}$ & $\begin{array}{l}\text { X1: And then I talked to S. What } \\
\text { it requires is to be in Co-Lead } \\
\text { management. And I told S. and } \\
\text { he said } \\
\text { X2: Ok. Look... we have to } \\
\text { sign the contract and then it's } \\
\text { easier for Michael, now he } \\
\text { feels like he's oppressed you } \\
\text { know... and there will be no } \\
\text { conversation. He's going to tell } \\
\text { Misu to go to hell and... that's } \\
\text { going to happen. } \\
\text { X1: No... but... yes... normal. } \\
\text { Ok... I don't know... But... You } \\
\text { know S. needs to be sure this is } \\
\text { going to happen in order to } \\
\text { stay ........ } \\
\text { Rămotină helped us in a very... }\end{array}$ \\
\hline
\end{tabular}

S. requires Co-Lead management and must be sure that this will happen20060411_130516/Interlocutors?

Table 16. Cryptographic or slang text reflectivity.

\begin{tabular}{lll}
\hline DATE / CODE & INTERLOCUTOR & REPLIES \\
\hline & & X1: Ok. Then see you later. \\
& Unknown & Or can I come now? \\
$20060411 \_130516$ & X1 & X2: Ok. No... later because \\
& X2 & I'm waiting for S. to come and \\
& & then I go out with him and... \\
& & Rămotină helped us in a \\
& & very... \\
\hline
\end{tabular}

S., a close friend of X2.

If we consider the analyzed communication style, a style that is characterized by a great freedom of choice of means of expression, along with the theme of communication which emphasizes the exchange of information and familiar address (Tati, Misen, Stamene, dottore, etc.) we can appreciate the fact that the group of interlocutors Stamen Stantchev, Mişene; G. K., R. D. identify with the unknown interlocutors, respectively $\mathrm{X} 1$ and $\mathrm{X} 2$.

A peculiarity of the dialogues is that the mentioned group of interlocutors uses a neutral way of addressing and indicating politely towards certain people, as in the case of $\mathrm{Z}$. N.

From this perspective, as well as the fact that the indicative S. is customized in the communications (R. D. and S. S. do NOT associate the indicatives $\mathrm{Z}$. and $\mathrm{S}$; ; in the same

Evidence in forensic linguistics has more power to eliminate someone as a suspect than to prove their guilt. Language experts are generally employed in criminal cases to defend a person suspected of a crime. Forensic linguists use their expertise in a variety of cases, including procedural abuse, where police statements have been found to be too similar or have been produced independently by police officers or to identify the perpetrator. texts, letters, messages, etc. 
communications the indicatives $\mathrm{S}$. and $\mathrm{Z}$. are used; $\mathrm{X} 2 \mathrm{~S}$. is a person known for a long time; $S$. requires Co-Lead management; S. can reconcile the interests of the company) it can be stated, without error, that the relationship Z. N.Schumacher - S. appears as an abstract triad indicating three (different) characters, consequently we exclude the synonymy Z. N.- Schumacher - S. ${ }^{12}$

\subsection{Testamentary Will Derived from External Documents and Surroundings}

Considering the principle according to which the testator's intention is sought mainly in the very content of the will, and in the alternative in external acts and circumstances, [9] we proceeded to examine them under the following reports:

The relationship between the content of the will and the external circumstances:

a) the external circumstance of the testator's knowledge of the orthographic and grammatical rules The notifications in the will do not respect the orthographic and grammatical rules.

b) The external circumstance of the knowledge of the legal terminology and of the forms of manifestation of the testamentary will by the testator. Notifications in the will do not comply with legal terminology.

The content of the will brings to light two relevant elements, specific to the method of servile imitation, namely the suggestion (to which the forgery writer was subjected) and the capture (conspiracy made in order to obtain by legal act benefits to the detriment of legal heirs). We quote:

"I make this will, because Rolescu G. Elisabeta Antonia cared for me for many years, with all my devotion and will take care of me, even in the future.

I also do it, because my two children gave me everything they needed and I did my duty as a parent a lot”.

The ratio between the content of the will and the typed note signed by... (codicil)

The preamble of the note,... notifies the situation of material and ideal wealth, making it known to both the legal heirs and the legatee. In fact, it customizes fractions of movable property starting with those in the house on the street...., no...., sector 1, Bucharest and notifies the satisfaction of fulfilling the natural duties it had regarding the conservation of wealth, growth and educating children.

At the end of the note,..., she formulates: “... and the one who has a will to dispose at will of what is due to her, choosing, taking and giving to each son, in relation to his behavior - what she wants", so that, in addition to the indication of the existence of a liberality in favor of the legatee.... ("and the one who has a will to dispose at will of his will" - forms for the future) the testator indicates that he gave the right in possession $^{13}$ of the legatee the part that belonged to him from the movable goods ${ }^{14}$, more precisely their handling "choosing,

12 Triad - in the dictionary sense of the abstract scheme of indicating three persons (different) Synonyms - in the dictionary sense of similarity (total correspondence)

13 The executor's will is not a proper sitting of the heirs. It does not give the executor any right of ownership over the estate or even a right of possession proper; the executor has only one detention, he possesses in the name of heresies.

14Art.911 C.civ.allows the testator to give the executor only possession of the taking, giving", designating it in this way as executor for a share of his own movable goods (share of sentimental goods) that belonged to the testator's sons in percentage left at the latitude of the binder. We note that in the content of the "will of July 15, 1994" there is no formulation with equivalence in the matter of testamentary execution (executors receive the task in the very content of the will).

As long as... he gave the legatee only a fraction of the movable property, the notification of the term "available quota" in the "will of July 15, 1994" does not belong to him. (available quota for both movable and immovable property).

Considering: * the conclusion of the graphoscopic examination "the will of July 15, 1994 is forged by forging the handwriting and the signature, the forger resorting to the method of servile imitation"; * the relationship between the content of the forged will and the external circumstances, respectively: the presence of spelling and grammatical errors, the notification of a terminology in contradiction with the established terminology, as well as the specific elements of the servile imitation method, suggestion and capture; * the relationship between the forged will and the intentional elements notified in the typed note (codicil), relating to the bequest of a fraction of all movable property and the provision equivalent to the appointment of the legatee as executor,

Concluded:

A will was notified in favor of the legatee, which had as object only the fraction of the movable goods located in the house from str...., no...., sector 1, Bucharest. (it is possible to reconstruct the shape made by the tester)

In the will notified by... was inserted a disposition relative to the handling of one's own fractions of movable goods (choosing, taking) together with a disposition with equivalence of testamentary execution (giving) in charge of the legatee and the benefit of the testator's sons (share of sentimental goods).

The form of the holographic will was used, given the advantage of being easily drawn up and kept secret until his death. Later, showing caution, he reaffirmed his will in the typed note that he signed and dated.

He took advantage of the disadvantages of the holographic will, namely the ease of being destroyed and forged by counterfeiting, thus changing the meaning of the testator's will in a new notification "will of July 15, 1994" subject to suggestion and capture, notification that could benefit his children... and....

GRAPHOLOGICAL DRAWING (THE TESTATOR) -From a graphological point of view, we systematize the following temperamental characteristics of the writer..., which we retain as external circumstances regarding the interpretation of the testamentary dispositions together with the testator's intention.

He had many reservations about life, he tried to be brave, to act positively, but he was secretly afraid of making mistakes. ${ }^{*}$ The attitude towards peach money was strongly

movable property. 
influenced by past experiences. He was very afraid of losing what he had, so he tried to keep what he had and gain more. * He covered his wounded feelings with a brave appearance, trying to look strong and firm. When he had difficult times, he did not allow anyone else to see how affected or disturbed he was. He tried to ignore the destructive criticism and comments. * He knew how to appreciate a joke and could be quite self-critical, even going so far as to laugh at himself and the situations in which he put himself. * He wanted others to respect and appreciate him, but he suspected they were not. So try to make a good impression as a way to hide any imperfections. * He liked to have fun. He wanted to be right where something was happening, to see and be seen. It was a great pleasure for her to get dressed and go to a special place. He was afraid of loneliness. ${ }^{*}$ He feared the future and how further developments would influence his status and interests. She was afraid of losing control. * Always open and sociable. He often told the story of his life without being invited to do so. He shared more special opinions and details from his personal life with anyone who wanted to listen to him. He could long for the attention of others. * Persevering, conscientious, unstoppable when dealing with something. His unlimited devotion made him a basic man at work, a person who did not give up until he caught all the details, until he anticipated all the possible consequences. You couldn't hide from him. * He had a strength of spirit, an iron will which, coupled with a specific purpose, produced astonishing results. * He liked to tell people what to do, to show them the right way to approach things. She believed that she was always right and that others should listen to her and follow her. He was embarrassed if contradicted. It was not easy to fight, whoever quarreled with him risked trouble. He struggled with personal issues that prevented him from openly expressing his true feelings.

\subsection{Testimony - Event Report}

Witnesses: D. M., V. A. and P. G. On October 12, 2000, around $2.30 \mathrm{pm}$, while driving with the cart on the road near Bîrlad, they saw a red Dacia car, driven by a 30-35 year old man, brunet who went to the place where the victim was found They see the car from a distance of about $10 \mathrm{~m}$, for a few seconds, from different positions and moments. D. M. is the only witness who testified that a woman was lying on the back seat of the car, with her head resting on the right window of the car. The other witnesses, although warned by D. M. of the woman's presence in the car, do not see her.

Witness data:

D. M., aged 20, 5 classes, comes from rural areas, low socio-economic and cultural status, unskilled worker.

The objectives of D. M's testimony analysis:

He stated that on 12.10.2000, around $2.30 \mathrm{pm}$, while he was in the wagon, he heard a car coming from behind, he turned his head to see the driver's intentions and to avoid the wagon in front of the car. At that moment he sees a red car, Dacia type, driven by a brunette man, aged about $30-35$ years, with short hair cut, with a high bangs and dyed blond, wearing a black blouse. He sees him in profile, when the car turns right. In the back seat of the car he sees a woman lying down. He only sees her head resting on the right window of the car.

Although he sees only the head of the person behind him, it is certain that she was a woman, unable to explain how he created this belief. When he saw the car, he thought it was a woman from the village who was walking with her boyfriend on the edge and hiding so that she would not be seen by them. Tell this to the people in the cart.

Testimony analysis:

Sincere testimony is a reflection of reality in terms of the subjectivity of the witness, and there is an "angle of deviation" between objective reality and its subjective reflection. In order to verify the "deflection angle" of the testimony, the sensory reception, the capacity to process, store and reactivate the information received, decoded and stored by the witness during the event were analyzed. [10]

The witness spontaneously perceives these things, for a few seconds, in good light (14.30, clear time), without any obstacle between him and the object of sensory reception, being at a higher height (the cart was at that time on a bridge). Both the cart and the car were moving. The perceived situation is simple, it does not require any cognitive effort or depth of thought to understand the meaning of those received. The only difference between D. M. and the statements of the other witnesses are related to the woman's presence in the car.

It had to be checked if he really saw a woman or expected to be a woman. He knew that pairs of young people usually walked on the edge, and expectation could lead to the interpretation of what was perceived ambiguously in the sense of expectation.

Witness D. M. has good visual and auditory acuity. At the time of sensory reception he was in a normal emotional state, he was not under the influence of alcohol or stress factors that would alter his emotional balance. Given the witness's position on the object of reception and the victim's position, it is very likely that he saw more of the victim's clothes that were brightly colored (orange, purple), unconsciously interpreting that they could only be a woman's clothes. Hence the witness's belief that there was a woman in the back seat of the car.

The testimony has a content that demonstrates an adequate, objective perception of the circumstances in the spatio-temporal context of the event that constitutes the object of the testimony.

Witness D. M. he presents himself as an emotional person, a state accentuated by the environment of the police institution (environment in which the initial discussion was held with him), by the novelty of the situation in which he was, as well as by his relatively limited social experience. Inferior socioeconomic status causes shy, restrained behavior with emotional blockages. He frequently stated "I don't know", "I didn't see" when asked for additional details to the path freely offered by him, details of which he is sure. Initially, she refuses to make the robot portrait of the man, being aware that based on the information retained, she cannot reconstruct his physiognomy. The question was to verify the extent to which emotion, as a temperamental trait of the witness, affected the 
quality of sensory reception.

Although in principle there were no facts, totally emotionally neutral situations, the situation perceived by the witness at the time of sensory reception did not affect his emotional balance. He perceives the situation neutrally, objectively, not knowing that this is how he becomes the main witness in a murder case. We can assume that the distortions produced by emotion are minimal, a fact demonstrated by maintaining the statement, in the same form over time.

Characterized by a concrete thinking, it does not show the tendency to interpret the perceived event, to find its hidden meanings or to fill in the gaps in the statement. D. M. describes things according to their external properties, objectifiable, not participating emotionally in the situation. Taking into account the content of the perceived situation, it does not activate attitudes of the witness that imply a certain expectation or a distortion of the reception. The witness has a medium level of psychomotor development and a good verbal ability. He fluently reports the received situation, presents the disposition to answer questions, as well as a resonant character of memories.

During the judicial experiment, the practical possibility of the witnesses to perceive the situation was verified. This clarified the differences between the testimonies, only from the position of D. M. being able to perceive the person in the back seat of the car. The other witnesses perceive the situation from different moments and positions, the car being already on the edge, the trees obstructing the visual field.

Conclusions:

In order to assess the extent to which it serves the cause under investigation, the testimony of D. M. it was analyzed from the point of view of fidelity, extension and the degree of subjective certainty. Following the analysis, it can be concluded that the testimony of $\mathrm{D}$. M. faithfully reproduce the received event, presenting a high degree of subjective certainty. There is a concordance between what he perceives and what he declares repeatedly, there are no special aspects that damage the essence of the testimony, the "angle of deviation" of reality being minimal.

Valorization of the testimony

The end of the criminal action - around $2.30 \mathrm{pm}^{15}$

The author drives a red car, Dacia type,

\subsection{Valorization of Free Relationship}

Free testimonial report "A. M. paid attention to Stefan, telling him that opposite, next to the sidewalk of the street at a distance of $15-20 \mathrm{~m}$ from the place where we were, there was a parked car and that they were in the car two people sitting there for nothing. Stefan didn't care.

At that moment, the car that was parked next to the sidewalk opposite, at a distance of no more than 15-20 m from our car, was set in motion and approached us. The driver was behind the wheel, and the man in the driver's seat got out.

15 In the back seat of the car he sees a woman lying down. He only sees her head resting on the right window of the car.
They stopped in front of the car in front of the car in the same alignment as in front of our car, but at approx. $1.5 \mathrm{~m}$ on the left side of our car.

Table 17. Valorization of the testimony.

\begin{tabular}{llll}
\hline Signal dynamic & $\begin{array}{l}\text { Static } \\
\text { signals }\end{array}$ & $\begin{array}{l}\text { Particular } \\
\text { signs }\end{array}$ & Clothing \\
\hline $\begin{array}{l}\text { Brunette man } \\
\text { Age 30-35 years }\end{array}$ & & $\begin{array}{l}\text { Head uncovered } \\
\text { Short hair, high bangs and } \\
\text { dyed blonde }\end{array}$ & Black blouse \\
\hline
\end{tabular}

Report on signals

Then I looked at the driver and saw that he had a long face, weak in the face, with a long nose, long hair on his shoulders and his head was touching the roof of the car, and his hair was behind his ears, as in women. I think he was 38-40 years old. When I stared at him, the driver turned his head to the right so that I could not see his face. Then I glanced at the one who had gotten out of the car.

The one who got out of the car, passed in front of his car and approached the left front door of our car at approx. $1 \mathrm{~m}$. He was a guy about approx. 40 years, height of approx. 1.75 athletic stature, weighing approx. $75 \mathrm{~kg}$, with olive face, round in the face, with thick and fleshy lips both upper lip and lower lip, being turned up and down and half-open. He had black hair, short haircut, like a brush. He had nothing on his head. On his body he had a kind of overcoat, I think, in a plaid, about knee-length, or even a little shorter than the knee, with a high collar.

Report on the psychological manifestation

When he approached us up to a distance of $1 \mathrm{~m}$, he had both hands in his coat pockets. He had a fixed, hard, motionless gaze. He made no gesture, as if it were a statue. He didn't ask us anything. It seemed to me that Stefan made a gesture with his left hand as if he wanted to either open the door or lower the window. However, he did not manage to do anything because the individual took his right hand out of his coat pocket and in his right hand he had a pistol, which he aimed at us and started firing automatically. It was a pistol with a longer barrel and a longer magazine, because I saw the bottom of the magazine under the fist of the hand in which he held the pistol.

As the individual began firing at us, I leaned my back against the back of the bench and protected my left face and ear with the palm of my left hand. Stefan was in the same position, raising his left hand from his shoulder and elbow to his face and leaning on his head with his head. The gust was extremely short and one.

After firing on us, the individual got into the car and the driver started suddenly from the spot, moving on Precupeţii Vechistreet from the northeast to southwest direction, he immediately turned right and disappeared ${ }^{16}$.

16 Being expressly asked by the prosecutor whether or not I noticed the clatter characteristic of finishing the ammunition on the barrel of the weapon, I declare that I did not notice such a thing. I was taken by surprise and I was extremely scared. 
Table 18. Capitalization relative to the individuality of the operating mode.

\begin{tabular}{lll}
\hline ITER CRIMINIS & MODUS PROCEDANDI & PUNCTUM SALIENS \\
\hline & $\begin{array}{l}\text { Victim - businessman (cars; garments; relations in the world of foreign and domestic } \\
\text { businessmen and in the underworld); }\end{array}$ & $\begin{array}{l}\text { uses modern weapon, with repeat } \\
\text { speed; } \\
\text { fake license plates; } \\
\text { Iter criminis traveled by car }\end{array}$ \\
& $\begin{array}{l}\text { How it was committed: waiting for the victim in front of the building where he lived; } \\
\text { shooting her while driving the car; } \\
\text { Organized: mathematical calculation regarding execution times; a modern, } \\
\text { high-performance weapon was used; }\end{array}$ & $\begin{array}{l}\text { possible clothing disguise; } \\
\text { used car }\end{array}$ \\
\hline
\end{tabular}

Table 19. Capitalization relative to biocriminalistic (physical) individuality. AUTHOR OF KILLING.

\begin{tabular}{|c|c|c|c|}
\hline SIGNAL DYNAMIC & STATIC SIGNALS & PARTICULAR SIGNS & CLOTHING \\
\hline $\begin{array}{l}\text { age of approx. } 40 \text { years } \\
1.75 \text { - athletic stature, approx. } 75 \mathrm{~kg}, \\
\text { olive face, round } \\
\text { thick, fleshy lips parted up and down and ajar. } \\
\text { black hair, short haircut, like a brush. }\end{array}$ & & & $\begin{array}{l}\text { He had nothing on his head } \\
\text { overcoat (possibly plaid,) knee-length, } \\
\text { with high collar. }\end{array}$ \\
\hline
\end{tabular}

Table 20. Capitalization relative to biocriminalistic (physical) individuality.

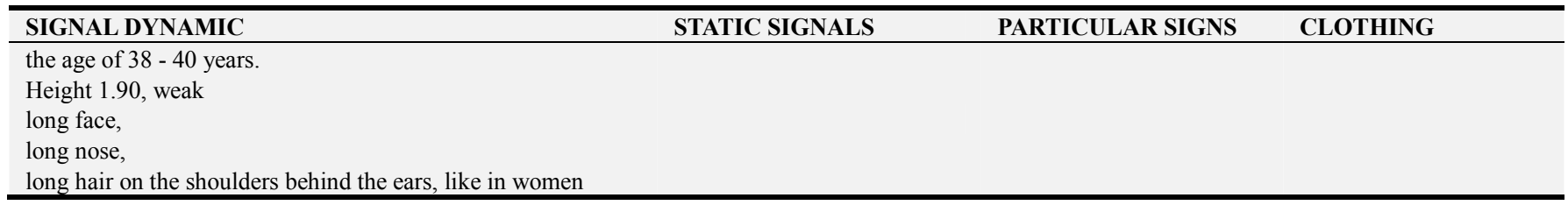

Table 21. Recovery regarding the elaboration of the follow-up form A. N. [11].

\section{PSYCHOLOGICAL REFERENCES}

a) Personality disorder - with the predominance of associative manifestations

* is not adapted to the rules of social life, by refusal. They generally do not show aggression

or hostility towards these rules, being indifferent to them;

* is distinguished by the desire to preserve their existential freedom and to protect

themselves from any psychosocial dependence;

b) Intelligence - average or above average;

c) Temperament - predominantly phlegmatic;

* critical of others and of what is happening;

* cold, unimpressive, unaffective;

d) It is organized - its actions are calculated, planned, it considers that there is a place for

everything and all must be in their place;

e) Self-image - positive, does not accept criticism, shows care for his person and his comfort;

f) Type of man - kind, vigilant, neat, with motor and reflex skills (reaction speed);

g) He is a cerebral - he waits for what he deserves, being sure that he will be given;

h) Does not act alone, but not with a third person.

$\mathrm{He}$ is loyal to the criminal partner he has chosen, appreciating calm and indifference.

Coincident biorhythms.

\section{SOCIOLOGICAL REFERENCES}

a) He practiced several types of trades and had several jobs; b) Geographically mobile, although he has a place where he keeps his favorite objects, which he takes care of (weapons) whenever he has the opportunity. Expresses concern for their impeccable functioning and for any personal property; c) We find him in an underworld, where he manifests self-confidence. Here his position is recognized, although his preoccupations are not known;

d) Has a criminal record and has been sentenced to deprivation of liberty. In the penitentiary he was withdrawn, he did not brag, but he controlled the leaders psychologically, thus ensuring his bio-psychic balance;

e) In the ordinary environment it is socially adapted. He wants to live alone. No one is good and safe enough for him. Owns a weapon: $9 \mathrm{~mm}$ pistol, five rifles - "SMITH WESSON", Parabellum ammunition, XTP class - Luger;

\subsection{Reconstruction of the Criminal Action Scene and Statement of the Suspect}

MOMENT 1. Applying the first blows to the victim. The area where the blood drops spread indicates:

a. the position of the victim, respectively at the wheel facing forward,

b. the position of the aggressor, in the middle of the rear seat,

c. the direction and dynamics of the blows (long strokes) from right to left, which caused the cut wounds split fronto - parietal right.

Along, the rapid stretching movement of the right arm engaged in the repeated application of blows, certainly excludes the hypothesis that to the right of the aggressor or on the right front seat was another person.

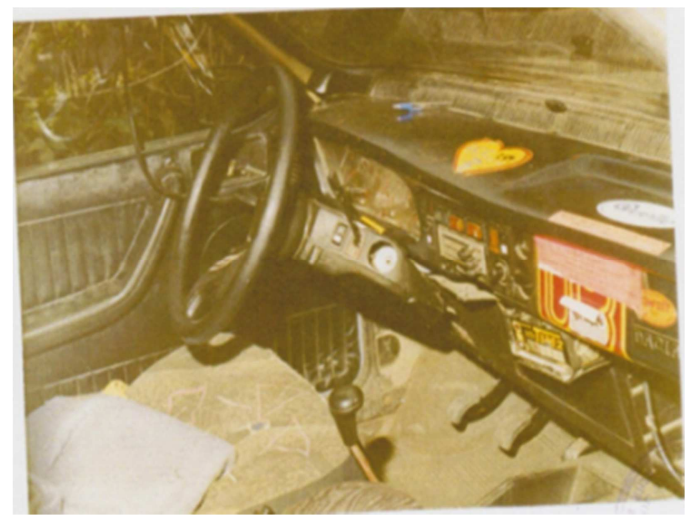

Figure 1. Guard the flag. 


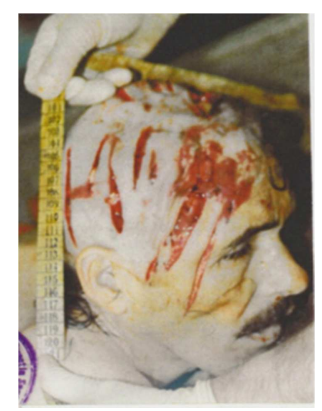

Figure 2. The position of the victim's head.

The cuts on the ceiling light clothing found after the on-site investigation, taken from the statement of the driver Dogariu Ioan who washed the car were created before the event, by repeated attempts to place a rod (pipes) in the car's passenger compartment. indicates that they do NOT reflect points in the trajectory corresponding to the blows received by the victim.

MOMENT 2.

The victim falls to the right side, respectively with his head on the right front seat, thus exposing the left frontal parietal part to the aggressor's blows, he strikes from the semi-bent position over the back of the seat.

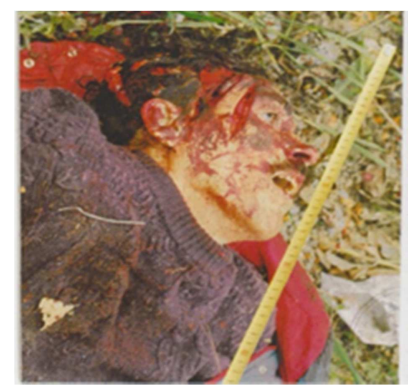

Figure 3. Areas corresponding to the folds.

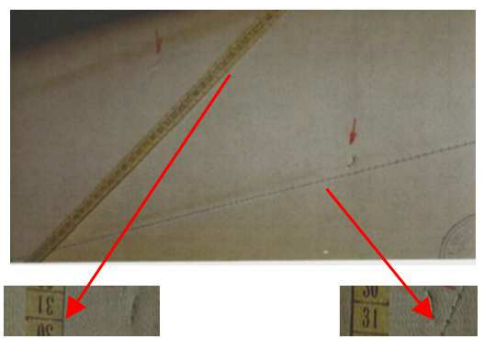

Figure 4. Victim falls to the right side.

\section{MOMENT 3.}

The aggressor gets out of the car, opens the right front door, pulls the victim's body and places it for a few moments on the right front seat in a lateral position (sitting on his right leg and his head slightly tilted to the outside of the cabin ${ }^{17}$ ).

17 Research report on the spot,..... "On the front-right seat it is observed that the seat clothing is soaked with a reddish-brown substance with a bloody appearance, between the two front seats, on the parking brake and a map of the municipality of Oradea there are drops of the same substance..... On the back carpet there is a reddish brown liquid leak with the appearance of blood, leaked through the right front seat.... where is the parking brake I found a lot of blood as well as brain debris and small pieces of the...."

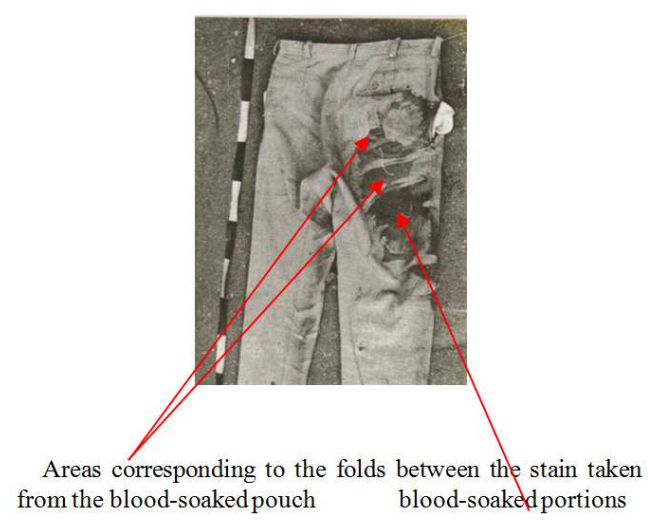

Figure 5. Areas corresponding to the folds.

Areas corresponding to the folds between the stain taken from the blood-soaked pouch blood-soaked portions

MOMENT 4

The aggressor assisted by a second person lowers the victim's body from the car and transports him in front of the car and bypassing it to the trunk. The last few meters the victim is lightly dragged, after which she is placed in the trunk.

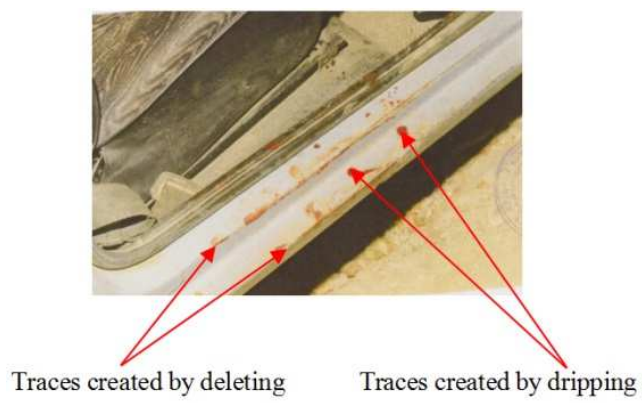

Figure 6. Traces created by deleting or dripping.
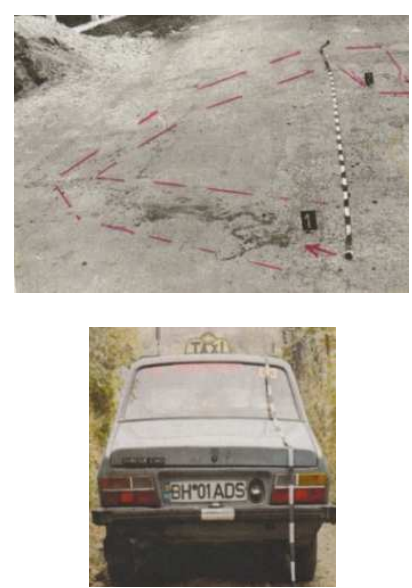

Figure 7. The location of the car

The location of the $\operatorname{car}^{18} /$ chips 1 and 2 indicates "the ends of the semicircular trace".

18 Minutes of the on-site investigation,..... Proceeding to the investigation of Faclieistreet... $500 \mathrm{~m}$ from this alley... next to the building with no. 44 on the road there is a trace of a semicircular shape, of stains and splashes of blood, at the ends having a higher consistency.... 


\section{MOMENT 5}

The person, who still had no traces of blood, got behind the wheel, turned the car around and drove down the street on the right (as he was walking towards the city). (followed or waited for the person who....

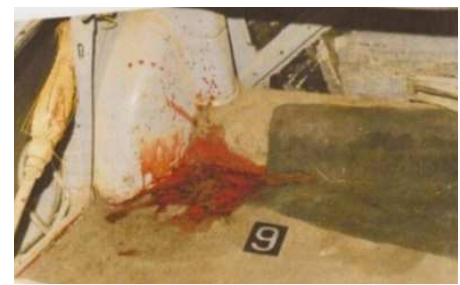

Figure 8. Stain blood on the trunk.

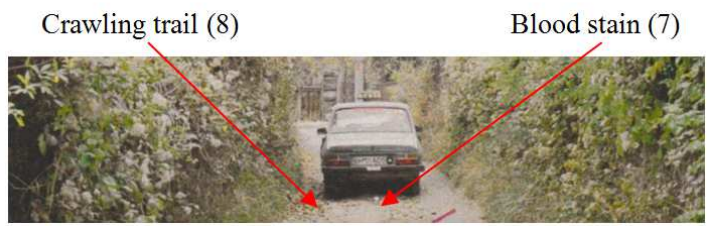

Figure 9. During which time blood stains form on the ground (a).
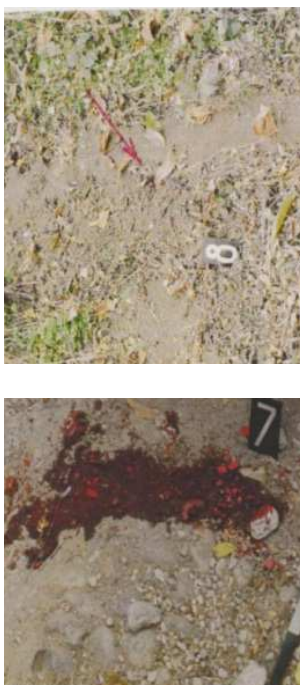

Figure 10. During which time blood stains form on the ground (b).

The corpse is removed from the trunk by gripping and pulling the chest (not by twisting). It is placed on the edge of the trunk, taken under the arms and legs after a few moments, during which time blood stains form on the ground (7).

With the pick-up from the edge of the trunk, there is a balance that surprises the person holding the corpse under his arms, a balance determined by the push made by the person holding the corpse by the legs and trying to make a better grip.

The backward swing causes the heel of the person's left shoe to hold the corpse under their arms to leave a trail of crawling on the sloping edge of the alley ${ }^{19}$.

MOMENTS 6. Transport of the victim. These moments are

19 Statements regarding the assumption of the criminal action / Moldoveanu Miha and Rorariu Ecaterina Gabriela do not refer to the established logical aspect. The crawl mark is on the same alignment with the place of the blood stain formed when the corpse was on the edge of the trunk to be taken in its arms. characterized by repeated imbalances due to the incoordination of the movements of the author and the accomplice ${ }^{20}$.

a. Moment of rebalancing by standing, footprints are formed (6)

b. Time of tearing and falling of the piece from the victim's shirt (5)

c. Moment of rebalancing by parking, footprints are formed (4)

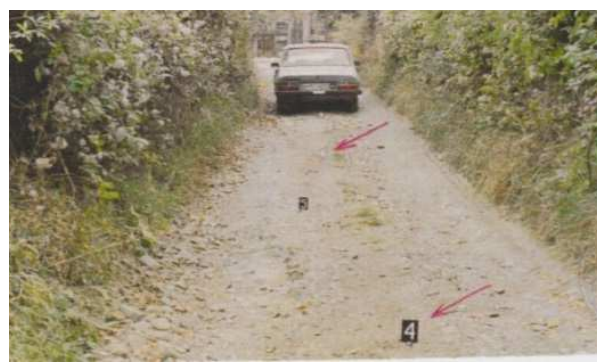

Figure 11. Transport of the victim.

d. The moment of weakening the grip of the corpse's hand, sliding on the arm, as a result of the fall of the clock (3).

e. The moment of losing the car keys held by the person who drove the car (2).

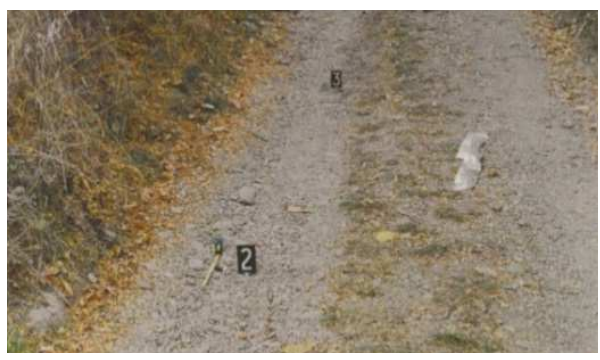

Figure 12. The moment of weakening the grip of the corpse hand.
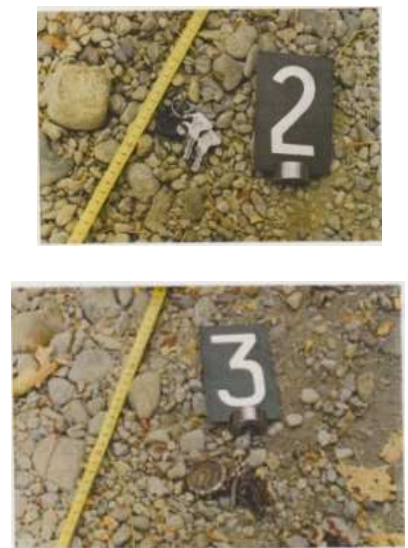

Figure 13. The moment of losing the car keys held by the person who drove the car.

f. Returning to the car, turning on the headlight to look for the keys.

20 Statements regarding the assumption of the criminal action / Moldoveanu Mihai and Rotariu Ecaterina Gabriel DO NOT refer to any of the aspects found during the on-site investigation. 
MOMENT 7

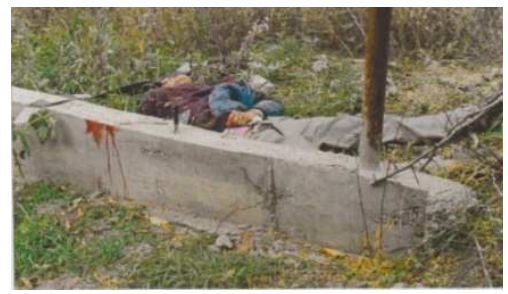

Figure 14. The corpse is thrown over the curb.

The corpse is thrown over the curb on the second attempt due to the initial impact of the concrete strip. The moment the corpse remains on the curb determines the formation of the blood trail.

The nature of the vulnerable instrument and the traces left by it

In this case, the lesions are destructive, leading to fractures of the bones, opening of the cavities and destruction of the contents encountered in the way of these cavities. The length and depth of the wounds, the space available to the aggressor, the direction, the force and the weight with which it handled the vulnerable instrument indicate its nature, respectively the sharp ax tool with a blade of about $9 \mathrm{~cm}$. Wounds formed with such a tool have the character of cut wounds and concomitant wounds.

Table 22. Comparative identification table (a). [12]

\begin{tabular}{|c|c|}
\hline & \\
\hline $\begin{array}{l}\text { Statements R. E. G., } \\
\text { "M. M. climbed in front next to the driver and H. and I climbed in the back... M. hit him with a metal } \\
\text { object like a jumper on the right side of his face several times, also the driver was hit by H. G. from } \\
\text { behind with a club } \\
\text { "G. was next to the driver, I was behind G., and M. was behind the driver. The first blow was applied } \\
\text { to the driver by M. with a kind of jumper and he was on the right side of the face, then G. hit him with } \\
\text { a club..... } \\
\text { "M. was behind the driver and I was to the right of the driver while G. was behind me" } \\
\text { Statements M. M. } \\
\text {.. to the right of the driver was Gabi, behind her was G., and I was behind the driver, R. E. G. in front, } \\
\text { G. behind her and I behind the driver } \\
\text { Statements R. E. G. } \\
\text { I was in the middle of the street, the driver stopped and while he was looking at me probably to make } \\
\text { him pay, M. who was behind him, hit him on the right side of the face with a sharp object in the form } \\
\text { of a cutter that did not I had seen them before. } \\
\text { The driver fell towards me, bleeding from his head, then G. hit him with the club, the driver tried to } \\
\text { get out of the car, but was caught by M., G. hit him again with the club, after which the driver managed } \\
\text { to get out car and started running towards the city but was zigzagging. } \\
\text { M. and G. got out of the car running after him, I also got out of the car, and I saw M. hitting the driver, } \\
\text { then G. hit him, knocking him down on the asphalt and continuing to hit him...... I saw the two of } \\
\text { them bringing the driver to the car..... }\end{array}$ & $\begin{array}{l}\text { MOMENT I - The area of propagation of blood } \\
\text { droplets indicates: a. The position of the victim, } \\
\text { respectively at the wheel facing forward; b. the } \\
\text { position of the aggressor, in the middle of the back } \\
\text { seat; c. the direction and dynamics of the blows } \\
\text { (elongation type blows) from right to left, blows that } \\
\text { caused the cut wounds - split right front parietal. } \\
\text { MOMENT II - The victim falls to the right side, } \\
\text { respectively with his head on the right front seat, } \\
\text { thus exposing the left front parietal part to the } \\
\text { aggressor's blows, he strikes from the semi-bent } \\
\text { position over the back of the seat. } \\
\text { Conclusion - The aggressor in the back seat applies } \\
\text { the first blows to the victim. The hypothesis of the } \\
\text { presence of some persons to the right of the } \\
\text { perpetrator or to the seat to the right of the victim is } \\
\text { excluded because the extension of the right arm of } \\
\text { the perpetrator in order to apply the blows would } \\
\text { have been blocked by the presence of some persons. }\end{array}$ \\
\hline
\end{tabular}

Table 23. Comparative identification table (b).

\begin{tabular}{|c|c|}
\hline $\begin{array}{l}\text { Statements of assumption } \\
\text { Criminal action }\end{array}$ & Reconstruction of criminal action \\
\hline $\begin{array}{l}\text { MOMENTS } 3,4,5,6 \text { are } \\
\text { not reflected in the } \\
\text { statements }\end{array}$ & $\begin{array}{l}\text { MOMENT III - The aggressor gets out of the car, opens the right front door, pulls the victim's body and places it for a few } \\
\text { moments on the right front seat in a lateral position (sitting on the right leg and head slightly tilted to the outside of the cabin). } \\
\text { MOMENT IV - The aggressor assisted by a second person lowers the victim's body from the car and transports him in front of } \\
\text { the car and bypassing it to the trunk. The last meters the victim is slightly dragged, after which she is placed in the trunk } \\
\text { MOMENT V - The person who was not yet showing traces of blood got behind the wheel, turned the car around and drove } \\
\text { down the street on the right (as he goes towards the city). (followed or waited for the person who... } \\
\text { The corpse is removed from the trunk by gripping and pulling the chest (not by twisting). It is placed on the edge of the trunk, } \\
\text { taken under the arms and legs after a few moments, during which time blood stains form on the ground. } \\
\text { With the pick-up from the edge of the trunk, there is a balance that surprises the person holding the corpse under his arms, a } \\
\text { balance determined by the push made by the person holding the corpse by the legs and trying to make a better grip. The } \\
\text { backward swing causes the heel of the left shoe of the person holding the corpse under his arms to leave a trail of crawling } \\
\text { highlighted on the sloping edge of the alley. } \\
\text { MOMENTS VI - transport of the victim } \\
\text { These moments are characterized by repeated imbalances due to the lack of coordination of the movements of the author and } \\
\text { his accomplice. a. Moment of rebalancing by parking / footprints are formed; b. The moment of tearing and falling of the piece } \\
\text { from the victim's shirt; c. Moment of rebalancing by standing, the traces of shoes are formed d. The moment of weakening the } \\
\text { grip of the corpse's hand, sliding on the arm, with the result of the clock falling; e. The moment of losing the car keys held by } \\
\text { the person who drove the car; f. Returning to the car, turning on the headlight to look for the keys }\end{array}$ \\
\hline
\end{tabular}

If the suspects had known the moments of the criminal action, the declaration of recognition would have had the following connotations ${ }^{21}$ :

21Conotation s. F. 1. (log.) The set of characteristics of an object; complex of 
".... I was in the car in the middle of the back seat, to my right and there were no other people $\mathrm{e}^{22}$ in the front right seat.

When stopping the $\operatorname{car}^{23}$.. (description of the visible part of the car of the street and its surroundings) I applied with........ (description of the vulnerable object) a number of about eight blows by extending the right arm, slightly bending the body towards right, and hitting the driver's face in a dynamic from right to top left. The driver fell sideways towards / on the right seat. I kept my position on the bench and with a slight bend I applied a series of blows again. The driver remained in this position until I got out of the car and opened the right front door.

I pulled the body into the space of the right ${ }^{24}$ seat. From here I took him out of the car, transported him bypassing the front of the car and placed him in the trunk with the help of.... (co-author) who grabbed him and lifted him by the legs. The co-driver, who still had no traces of blood............. got behind the wheel, turned the car around and followed me down the street on the right ${ }^{25}$ (as I walk towards the city) walking ${ }^{26 .}$ At the end of the street I noticed........... (?) And decided to abandon the body on the opposite side ${ }^{27}$.

I went to the trunk followed by..... (co-author), I took the corpse under his arms like the first time,......... (co-author) took him by the legs and together we carried him, with several difficulties ${ }^{28}$ until the end of the street where from the second attempt I threw it over a curb. Returning to the car.... (co-author) found that he lost his ignition keys, turned on the headlight in search of the keys that were not found. This fact determined us to abandon the car as well".

\section{Conclusions}

Semantics, a branch of linguistics, studies the meaning of words and sentences, with the aim of clarifying the extent to which the meaning and significance of complex notions can be derived from the simplest symbols of language in general,

characters that belong to a concrete situation.

22 The space above the level of the back seat of the right front and the corresponding one to the right of the author is the manifest space of the dynamics of the vulnerable object. If there was another person in the car, his position could only be to the left of the author.

23 It is natural that the stopping of the car was made at the request of the author after viewing the area.

24 Soaking the right seat cover with blood causes a certain amount of blood to drain in a certain unit of time. Idem.

25 Soaking the right seat cover with blood causes a certain amount of blood to drain in a certain unit of time.

26 This position is reflected by the positioning of the traces of blood on the victim's pants.

27 The intervention only at this moment of the second person (co-author) is explained by the traces of crawling in a semicircle, respectively the transport of the corpse by one person, and the trace of leakage from the trunk with the significance of placing the corpse. The ascent of the corpse in the trunk by a single person would have been reflected by the traces of throwing and rolling, traces that are missing. 28 The on-site investigation and the subsequent statement of the person who washed the car do not indicate traces of blood on the rear seat and the driver's seat The seat on the right could not be used due to its soaking in blood. The transport of the corpse caused the blood to soak in the chest and leaked on the rest of the clothes of the person who caught the corpse under his arms. The imminence of the transfer of traces of blood to the objects with which it subsequently came into contact must be taken into account. and why not, of language reflected by evidence. and judicial evidence. Knowing the meaning and significance of the notions, we notice the evidentiary procedures and the means of proof that reflect states of tension, more precisely, the existence of several meanings or a confused meaning.

Psychoanalysis encompasses a number of concepts regarding the explanation of psychic phenomena. Extending through independent research these conceptions to the explanation of legal phenomena, I found that I am in fact developing a therapy of the unknown, errors, and subjectivism, as objectives of criminal investigation.

In essence, semantics helps us to understand the meaning of words and sentences, and in this way to detect states of tension in evidence and means of proof, and psychoanalysis helps us to know the transient states of the minds of justices, states that have influenced what what they thought and how they looked at the actual situations. Thus we establish and apply methods and procedures necessary to eliminate the unknowns, errors and subjectivism.

\section{Acknowledgements}

Thank you from the bottom of my heart for your invitation. The opportunity to publish and be a member of the editorial board is especially honorable. It can be said that I am fortunate to be with an independent academic editor with an editorial team that includes many of the most important researchers in the world, dedicated to advancing innovation and excellence for the benefit of humanity.

\section{References}

[1] Abric, J. Cl., (2002), Psychology of communication - Theories and methods, Polirom Publishing House, Iaşi.

[2] Narcis Giurgiu - General criminal law Ed. Cantes / Iasi 2000.

[3] Emilian Stancu, Tratat criminalistic, Editura Universul Juridic 2010.

[4] Eugen Horovanu - Principles of judicial procedure Lupta Publishing House, Bucharest 1932.

[5] Gheorghe Mateut - Ed. Procedură penală. Chemarea / Iasi 1997.

[6] Dan Dermengiu, Gheorghe Alexandrescu "Prosectural Forensic Medicine" Ed. 2012.

[7] Altman, M., Concerning Tchebyshev's Generalized Method of solving nonlinear functional Equations, Bull. del'Acad. Polonaise de Sciences ( $\mathrm{S}^{\prime}$ erie des sciences math' ematiques, astronomiques et physiques) vol. IX (4), 261-266, (1961).

[8] MALEY, Yon. The Language and the Law. Edited by John Gibbons. London: Longman, 1994.

[9] Dimitrie Alexandresco - Principles of civil law Socec\& co Publishing House Bucharest 1924.

[10] T. Butoi, Behavioral analysis in criminal proceedings, Ed. Pro Universitaria. 
[11] N. Zamfirescu, Logica cercetarii criminale Ed. Print Euro Ploiesti 1998.
[12] Sorin Alamoreanu, N. Zamfirescu, Phenomenological Interpretation of Traces, Alma Mater Publishing House, 2004. 